\title{
KAJIAN METODE SMALL AREA ESTIMATION UNTUK MENDUGA TINGKAT PENGANGGURAN TERBUKA
}

\author{
Budi Hartono ${ }^{1}$, Risma Hapsari ${ }^{2}$ \\ ${ }^{1}$ Badan Pusat Statistik Provinsi Jambi \\ budihar@bps.go.id, hapsari@bps.go.id
}

\begin{abstract}
Statistics Indonesia (BPS) is nationally responsible for the availability of data required for sectoral and cross sectoral development planning in Indonesia. The main source of employment data in Indonesia is National Labour Force Survey (Sakernas). Since 2015 Sakernas has been conducted in semester period, i.e. February and August. Sakernas February to produces employment indicators up to province level, while Sakernas August to district/regency level. In 2016, Sakernas August not produced employment indicators in district/regency level because inadequate size samples. The Small Area Estimation (SAE) method is an alternative that can be used to estimate the parameters in an area when the sample size in the area is too small to obtain adequate precision compared to the direct estimation. This research applies the proposed SAE Zero Inflated Binomial (ZIB) method to unemployment data at the village unit level and estimate proportion of unemployment in each district/regency during period August 2016 in Jambi Province, Indonesia. The application to unemployment data results that the proportion estimate of SAE ZIB method is similar with the current publication (4 unemployments of 100 labor forces) in Province Jambi level and can produces employment indicators during period August 2016 in district/regency level.
\end{abstract}

Keyword: small area estimation, unemployment, zero inflated binomial.

Abstraksi. Badan Pusat Statistik (BPS) bertanggung jawab secara nasional terhadap ketersediaan data yang diperlukan untuk perencanaan pembangunan sektoral maupun lintas sektoral di Indonesia. Data yang digunakan untuk perencanaan pembangunan di bidang ketenagakerjaan, dikumpulkan melalui Survei Angkatan Kerja Nasional (Sakernas). Sejak 2015, Sakernas didesain dengan menggunakan metode Three Stage Sampling (Panel Blok Sensus) dan dilaksanakan dengan waktu setiap semesteran, yaitu pada bulan Februari dan Agustus. Metode pendugaan area kecil merupakan alternatif yang dapat digunakan untuk menduga parameter pada suatu area dengan presisi yang memadai ketika ukuran contoh pada area tersebut terlalu kecil. Penelitian ini melakukan pendugaan area kecil dengan menggunakan model Zero Inflated Binomial untuk menduga Tingkat Pengangguran Terbuka (TPT) tingkat kabupaten/kota pada periode Agustus 2016 di Provinsi Jambi, Indonesia. Hasil dugaan TPT Provinsi Jambi dengan metode SAE ZIB sama dengan yang dipublikasikan oleh BPS, yaitu terdapat 4 (empat) orang menganggur dari 100 orang angkatan kerja. Metode pendugaan area kecil dengan model Zero Inflated Binomial dapat menghasilkan dugaan TPT Agustus 2016 tingkat kabupaten/kota di Provinsi Jambi yang sebelumnya tidak dihasilkan oleh BPS karena ketidakcukupan contoh.

Kata kunci: pendugaan area kecil, pengangguran, zero inflated binomial.

\section{PENDAHULUAN}

Badan Pusat

bertanggung jawab
Statistik

(BPS)

secara nasional terhadap ketersediaan data yang diperlukan untuk perencanaan pembangunan sektoral maupun lintas sektoral di Indonesia. Di 
Indonesia, data partisipasi angkatan kerja yang digunakan untuk perencanaan pembangunan di bidang ketenagakerjaan, dikumpulkan melalui Survei Angkatan Kerja Nasional (Sakernas). Secara umum, tujuan pengumpulan data melalui Sakernas adalah menyediakan data pokok ketenagakerjaan yang berkesinambungan. Secara khusus, untuk memperoleh dugaan data jumlah penduduk bekerja, jumlah pengangguran, dan indikator ketenagakerjaan lainnya serta perkembangannya di tingkat kabupaten/kota, provinsi, maupun nasional.

Sejak 2015, Sakernas didesain dengan menggunakan metode Three Stage Sampling (Panel Blok Sensus) dan dilaksanakan dengan waktu setiap semesteran, yaitu pada bulan Februari (Semester I) dan Agustus (Semester II). Sakernas Februari didesain memiliki ketelitian yang memadai untuk pendugaan di tingkat provinsi dan nasional, padahal informasi tentang ketenagakerjaan pada tingkat yang lebih rendah dari provinsi (kabupaten/kota, kecamatan, dan desa/kelurahan) serta perubahannya yang dapat dipantau dalam waktu yang relatif singkat sangat diperlukan seiring dengan perkembangan otonomi daerah.

Jumlah contoh Sakernas Agustus seharusnya sebanyak 20.000 Blok Sensus (BS), yang terdiri dari 5.000 BS contoh Sakernas Februari dan 15.000 BS merupakan contoh Sakernas tambahan untuk memperoleh dugaan data ketenagakerjaan hingga tingkat kabupaten/kota. Pada tahun 2016, penambahan contoh pada Sakernas Agustus tidak dilakukan sehingga jumlah contoh Sakernas Agustus sama dengan jumlah contoh Sakernas Februari. Hal ini menyebabkan ketidakcukupan contoh ketika akan melakukan pendugaan berbagai indikator ketenagakerjaan pada tingkat kabupaten/kota. Oleh karena itu, pada tahun 2016 publikasi angka pengangguran yang dikeluarkan oleh BPS hanya hingga tingkat provinsi dan tidak tersedia angka penggangguran pada tingkat kabupaten/kota sebagaimana tahun-tahun sebelumnya.

Terdapat permasalahan dalam berbagai pendugaan indikator ketenagakerjaan semesteran di tingkat kabupaten/kota, yaitu ketidakcukupan ukuran contoh. Jika penghitungan indikator ketenagakerjaan tingkat kabupaten/kota dilakukan secara langsung tanpa penambahan contoh, maka disebut sebagai pendugaan langsung yang dihadapkan dengan masalah besarnya galat baku yang dihasilkan sebagai akibat dari kecilnya ukuran contoh serta dipaksakan untuk mendapatkan penduga area kecilnya. Masalah tersebut menjadi alasan perlunya metode pendugaan dengan cara tidak langsung yang dapat mengurangi galat baku.

Untuk menyelesaikan masalah tersebut, perlu mempelajari bagaimana menduga parameter tingkat kabupaten/kota berdasarkan survei ketika ukuran contoh tidak mencukupi. Model pendugaan area kecil merupakan alternatif yang dapat digunakan untuk menduga parameter pada suatu area ketika ukuran contoh pada area tersebut terlalu kecil untuk mendapatkan presisi yang memadai dibandingkan ketika dilakukan pendugaan secara langsung (Rao, 2003).

Permasalahan lain yang dihadapi dalam analisis data pada data survei adalah sering dijumpai data yang ragam pengamatannya lebih besar dari ragam teoritisnya. Keadaan ini lebih dikenal dengan overdispersi. Salah satu penyebab 
terjadinya overdispersi adalah terlalu banyak nilai nol (excess zeros) pada peubah respon yang diamati. Model Zero Inflated Binomial (ZIB) merupakan salah satu metode yang dapat digunakan untuk mengatasi banyaknya nilai nol (excess zeros) dalam data respons bertipe biner.

Menganggur adalah kejadian biner dengan dua kemungkinan, yaitu menganggur atau tidak menganggur (bekerja). Respon biner dengan peluang berhasil (mengganggur), $\pi$, dan batas atas (n angkatan kerja) pada umumnya mengikuti sebaran Binomial (n, $\pi$ ), selanjutnya data jumlah pengangguran diasumsikan mengikuti sebaran Binomial. Sakernas Agustus 2016 menghasilkan data jumlah pengangguran hingga tingkat provinsi, tetapi ketika dilakukan pendugaan langsung pada level unit desa/kelurahan banyak unit (60.61 persen) yang jumlah penganggurannya bernilai nol (zero inflated) yang berarti tidak ada pengangguran di desa/kelurahan tersebut. Dengan demikian, data jumlah pengangguran pada tingkat desa/kelurahan kondisi Agustus 2016 diasumsikan mengikuti sebaran Binomial dan terjadi overdispersi. Banyaknya nilai nol pada peubah yang menjadi perhatian menyebabkan ketidaktepatan sebaran, pendekatan yang tepat adalah dengan menggunakan Zero Inflated Binomial.

Penelitian ini melakukan pendugaan area kecil dengan menggunakan model Zero Inflated Binomial untuk menduga Tingkat Pengangguran Terbuka (TPT) tingkat kabupaten/kota pada periode Agustus 2016 di Provinsi Jambi, Indonesia.

\section{METODE PENELITIAN}

Menurut Rao (2003) penyertaan peubah ikut berperan dalam mempengaruhi pendugaan tidak langsung dalam menghasilkan dugaan yang lebih akurat. Kriteria pemilihan peubah penyerta yang digunakan dalam penelitian ini difokuskan pada beberapa literatur dan penelitian tentang pengangguran serta ketenagakerjaan yang pernah dilakukan sebelumnya.

Penelitian ini mengaplikasikan metode pendugaan area kecil dengan model Zero Inflated Binomial (SAE ZIB) pada data pengangguran untuk mengatasi banyaknya nilai nol dalam data Binomial di level unit desa/kelurahan dan menduga TPT di setiap kabupaten/kota. Jumlah unit penelitian adalah sebanyak 99 desa/kelurahan yang tersurvei (j) pada Sakernas Agustus 2016. Parameter yang akan diduga $\left(y_{i j}\right)$ adalah jumlah pengangguran di 99 desa/kelurahan, dimana $\mathrm{j}=1, \ldots, 99$. Berdasarkan dugaan jumlah pengangguran tersebut, kemudian dihitung TPT di 11 kabupaten/kota di Provinsi Jambi.

Peubah penyerta yang digunakan dalam penelitian ini bersumber pada data Podes 2014, yaitu persentase penduduk laki-laki (X1), persentase keluarga pertanian (X2), jumlah Surat Keterangan Miskin (SKM) yang dikeluarkan pemerintah desa (X3), jumlah SMA/SMK/MA dan Perguruan Tinggi (X4), jumlah industri (X5), jumlah pasar dan pertokoan (X6), dan jumlah hotel dan penginapan (X7).

Tahapan-tahapan penelitian yang digunakan pada data pengangguran adalah sebagai berikut:

1. Mengolah data mentah hasil pencacahan Sakernas Agustus 2016 menjadi data jumlah pengangguran 
$\left(y_{i j}\right)$ yang menjadi peubah respon yang diamati dalam penelitian ini.

- Mengelompokkan individu menjadi dua kelompok, yaitu penduduk usia kerja (penduduk yang berumur 15 ke atas) dan penduduk bukan usia kerja (penduduk yang berumur dibawah 15 tahun).

- Mengelompokkan penduduk usia kerja menjadi dua kelompok, yaitu kelompok angkatan kerja dan bukan angkatan kerja. Angkatan kerja adalah individu yang dalam seminggu terakhir bekerja, tidak bekerja, dan sementara tidak bekerja. Bukan angkatan kerja adalah individu yang dalam seminggu terakhir bersekolah, mengurus rumah tangga, atau lainnya.

- Menghitung jumlah individu yang bekerja dan sementara tidak bekerja di setiap desa/kelurahan.

- Menghitung jumlah individu yang tidak bekerja (pengangguran) di setiap desa/kelurahan $\left(y_{i j}\right)$.

- Menghitung jumlah angkatan kerja di setiap desa/kelurahan.

2. Melakukan pembobotan $\left(w_{i j}\right)$ pada setiap peubah yang menjadi perhatian $\left(y_{i j}\right)$ dengan $w_{i j}=\left(\frac{H H_{i j}}{h h_{i j}}\right) /\left(\sum_{\forall j} \frac{H H_{i j}}{h h_{i j}}\right)$

dimana,

$h h_{i j} \quad$ : jumlah contoh rumah tangga dari kabupaten/kota ke-i desa/kelurahan ke-j

$H H_{i j}$ : jumlah populasi rumah tangga dari kabupaten/kota ke-i desa/kelurahan ke-j

3. Memilih peubah yang masuk dalam model $\operatorname{logit}(\pi)$ dan $\operatorname{logit}(p)$, melakukan pemodelan ZIB pada data angka pengangguran, kemudian memodelkannya ke dalam SAE ZIB.

4. Menduga parameter dari $\operatorname{logit}(\pi)$ dan $\operatorname{logit}(p)$ dengan menggunakan metode SAE ZIB.

5. Menghitung dugaan jumlah pengangguran untuk unit tersurvei $\left(\hat{\mathrm{y}}_{\mathrm{ij}}\right)$

- $\hat{\pi}_{i j}=\left(\exp \left(\operatorname{logit}\left(\hat{\pi}_{i j}\right)\right)\right) /\left(1+\exp \left(\operatorname{logit}\left(\hat{\pi}_{i j}\right)\right)\right)$

- $\hat{p}_{i j}=\left(\exp \left(\operatorname{logit}\left(\hat{p}_{i j}\right)\right)\right) /\left(1+\exp \left(\log i t\left(\hat{p}_{i j}\right)\right)\right)$

- $\hat{\mathrm{y}}_{\mathrm{ij}}=n_{\mathrm{ij}} \mathrm{x} \hat{\pi}_{\mathrm{ij}} \mathrm{x}\left(1-\hat{\mathrm{p}}_{\mathrm{ij}}\right)$

6. Menggunakan dugaan yang diperoleh pada langkah (5) untuk menghitung dugaan:

- Proporsi dari $\widehat{\mathrm{y}}, \widehat{\operatorname{prop}}_{i}=\frac{1}{n_{\mathrm{i}}}\left(\sum_{\mathrm{wj}_{\mathrm{j}}} \widehat{\mathrm{y}}_{\mathrm{ij}}\right)$

Dugaan TPT $=\widehat{\text { prop }}_{i} \times 100$

- Aproksimasi Kuadrat Tengah Galat dengan menggunakan galat baku yang diperoleh berdasarkan rumus ragam Hall (2000) dimana,

$\operatorname{Var}\left(y_{i}\right)=\left(1-p_{i}\right) n_{i} \pi_{i}\left[1-\pi_{i}\left(1-p_{i} n_{i}\right)\right]$

Aproksimasi Kuadrat Tengah Galat dengan galat baku untuk proporsi,

$\operatorname{Var}\left(\frac{Y_{i}}{n_{i}}\right)=\frac{1}{\mathrm{n}_{\mathrm{i}}^{2}}\left(\left(1-\hat{\mathrm{p}}_{i}\right) \times \mathrm{n}_{\mathrm{i}} \times \hat{\pi}_{i}\left[1-\hat{\pi}_{i} \times\left(1-\hat{\mathrm{p}}_{i} \times \mathrm{n}_{\mathrm{i}}\right)\right]\right)$

- Galat baku dari proporsi/TPT,

$\widehat{\mathrm{S}}_{\text {proporsi,i }}=\sqrt{\frac{1}{n_{i}^{2}}\left(\left(1-\hat{p}_{i}\right) \times n_{\mathrm{i}} \times \hat{\pi}_{i}\left[1-\hat{\pi}_{i} \times\left(1-\hat{\mathrm{p}}_{i} \times n_{\mathrm{i}}\right)\right]\right)}$

7. Membandingkan hasil dugaan TPT dengan Tingkat Pengangguran Terbuka (TPT) publikasi BPS.

\section{HASIL DAN PEMBAHASAN}

Jambi sebagai salah satu provinsi di Sumatera. Sebelah utara berbatasan dengan Provinsi Riau dan Kepulauan Riau, sebelah timur berbatasan dengan Laut Cina Selatan, bagian selatan berbatasan dengan Provinsi Sumatera Selatan, dan barat berbatasan dengan Provinsi Sumatera Barat dan Bengkulu. Posisi Provinsi Jambi cukup strategis karena langsung berhadapan dengan kawasan pertumbuhan 
ekonomi IMS-GT (Indonesia, Malaysia, Singapura Growth Triangle). Letak astronomisnya antara $0^{\circ} 45^{\prime}$ dan $2^{\circ} 45^{\prime}$ Lintang Selatan serta antara $101^{\circ} 10^{\prime}$ dan 104 $55^{\circ}$ ' Bujur Timur. Provinsi Jambi mempunyai luas $53.435 \mathrm{Km}^{2}$, dengan luas daratan 50.160,05 $\mathrm{Km}^{2}$ dan luas perairan sebesar 3.274,95 $\mathrm{Km}^{2}$. Luasan tersebut merupakan 2,62 persen dari total luas daratan Indonesia, dan sebesar 10,4 persen dari total luas daratan pulau Sumatera. Provinsi Jambi memiliki 9 (sembilan) kabupaten, 2 (dua) kota, 138 kecamatan, 1.399 desa, dan 163 kelurahan.

Berdasarkan publikasi data ketenagakerjaan BPS hasil Sakernas Agustus 2016, Tingkat Partisipasi Angkatan Kerja Provinsi Jambi tahun 2016 sebesar 67,54. Hal ini memberikan gambaran bahwa dari total penduduk usia kerja (15 tahun ke atas), sekitar 67,54 persen termasuk dalam angkatan kerja. Angkatan kerja merupakan penduduk usia 15 tahun dan lebih yang bekerja, mempunyai pekerjaan namun sementara tidak bekerja, dan pengangguran. Penduduk yang termasuk bukan angkatan kerja adalah penduduk usia kerja (15 tahun atau lebih) yang masih sekolah, mengurus rumahtangga, atau melaksanakan kegiatan lainnya selain kegiatan pribadi. Pada tahun 2016, angkatan kerja di Provinsi Jambi meningkat sebesar 4,41 persen dari tahun sebelumnya.

Tingkat Partisipasi Angkatan Kerja (TPAK) 2016 mengalami peningkatan dibanding tahun 2015 yaitu dari 66,14 persen menjadi 67,54 persen. Angka tersebut mengindikasikan besarnya persentase penduduk usia kerja yang secara aktif secara ekonomi. Meningkatnya nilai TPAK menunjukkan bahwa semakin tinggi pula pasokan tenaga kerja yang tersedia di Provinsi Jambi.
Pasar tenaga kerja Provinsi Jambi ditandai dengan tingginya angka kesempatan kerja. Hal ini dapat dilihat pada tingginya persentase penduduk usia kerja yang bekerja, besarnya mencapai 96 persen. Kesempatan kerja terus meningkat pada periode tahun 2014 - 2016. Meningkatnya kesempatan kerja pada periode tersebut selaras dengan peningkatan Upah Minimum Provinsi (UMP) Jambi. Selama periode 2014 2016 UMP Provinsi Jambi selalu meningkat hingga pada tahun 2016 sebesar 1,9 juta rupiah.

Berdasarkan perbandingan menurut tiga sektor utama, pilihan bekerja di sektor Pertanian masih mendominasi pasar kerja di Provinsi Jambi dengan persentase sebesar 49 persen pada tahun 2016, yang diikuti dengan sektor Perdagangan dengan persentase sebesar 18 persen, serta sektor Jasa Kemasyarakatan sebesar 15 persen.

Ditinjau berdasarkan tingkat pendidikan tertinggi yang telah ditamatkan, penduduk yang bekerja sebesar 38,70 persen dari seluruh penduduk di Provinsi Jambi. Diantara penduduk bekerja, yang terbesar adalah berpendidikan Sekolah Dasar (SD) sebesar 29,17 persen dan selanjutnya berpendidikan Sekolah Menengah Atas (SMA) sederajat yaitu sebesar 27,46 persen. Penduduk bekerja dengan tingkat pendidikan tinggi yaitu Diploma Satu ke atas jumlahnya paling sedikit diantara seluruh jenjang pendidikan, hanya sebesar 11,11 persen. Jumlah pengangguran menurun sebesar 3,80 persen dan tingkat pengangguran menurun dari 4,34 persen menjadi 4,00 persen pada kurun waktu 2015-2016.

Bila diklasifikasikan menurut status pekerjaan utama, maka sebagian besar penduduk yang bekerja berstatus sebagai 
buruh/pegawai yaitu sebesar 33,79 persen. Selanjutnya diikuti penduduk yang berusaha sendiri (20,73 persen), berusaha dibantu buruh tidak tetap (17,79 persen), pekerja keluarga (16,81 persen), dan pekerja bebas serta pekerja berusaha dibantu buruh tetap persentasenya di bawah 10,00 persen.

Tingkat Pengangguran Terbuka (TPT) Provinsi Jambi dilihat lebih rinci tiap kabupaten/kota tergambar dari Tabel 1. Dari tahun 2012 sampai tahun 2017 terlihat bahwa TPT di kabupaten/kota di Provinsi Jambi mengalami fluktuasi. BPS selalu mengeluarkan publikasi TPT setiap tahun berdasarkan hasil Sakernas yang dilaksanakan pada bulan Agustus, kecuali pada tahun 2016. Hal ini dikarenakan pada tahun 2016, penambahan contoh pada Sakernas Agustus tidak dilakukan sehingga jumlah contoh Sakernas Agustus sama dengan jumlah contoh Sakernas Februari. Oleh karena itu, pada tahun 2016 publikasi TPT yang dikeluarkan oleh BPS hanya hingga tingkat provinsi dan tidak tersedia TPT pada tingkat kabupaten/kota sebagaimana tahun-tahun sebelumnya. Tujuan dalam aplikasi metode ini adalah untuk menghasilkan penduga Tingkat Pengangguran Terbuka (TPT) tingkat kabupaten/kota periode Agustus 2016.

Tabel 1.

TPT Kabupaten/Kota di Provinsi Jambi tahun 2012-2017

\begin{tabular}{lcccccc}
\hline Kabupaten/Kota & 2012 & 2013 & 2014 & 2015 & 2016 & 2017 \\
\hline Kerinci & 4,42 & 7,13 & 4,44 & 3,67 & - & 3,26 \\
Merangin & 2,80 & 6,01 & 2,55 & 5,38 & - & 4,10 \\
Sarolangun & 1,91 & 3,64 & 4,13 & 4,53 & - & 2,25 \\
Batang Hari & 3,06 & 5,94 & 5,69 & 3,38 & - & 3,57 \\
Muaro Jambi & 2,43 & 2,78 & 4,36 & 5,40 & - & 5,39 \\
Tanjung Jabung Timur & 2,12 & 3,53 & 1,73 & 1,44 & - & 2,36 \\
Tanjung Jabung Barat & 2,77 & 4,90 & 1,34 & 2,68 & - & 3,07 \\
Tebo & 2,10 & 0,73 & 3,86 & 1,94 & - & 1,98 \\
Bungo & 3,43 & 4,38 & 6,34 & 2,98 & - & 4,89 \\
Kota Jambi & 4,89 & 7,44 & 10,13 & 7,32 & - & 5,55 \\
Kota Sungai Penuh & 6,57 & 5,12 & 10,81 & 8,18 & - & 4,14 \\
\hline Provinsi Jambi & 3,20 & 4,76 & 5,08 & 4,34 & 4,00 & 3,87 \\
\hline
\end{tabular}

Tabel 2 menyajikan statistik deskriptif dari peubah penyerta yang akan digunakan pada pemodelan area kecil. Dalam melakukan pembandingan model SAE ZIB digunakan beberapa peubah penyerta dari Podes 2014 yang secara teori bisa mempengaruhi besarnya tingkat pengangguran. Peubah-peubah penyerta tersebut menggambarkan kondisi di masyarakat yang diduga memiliki pengaruh terhadap jumlah pengangguran.
Data peubah penyerta yang digunakan menggambarkan kondisi seluruh desa/kelurahan di Provinsi Jambi. Terlihat bahwa sebagian besar keluarga di Provinsi Jambi adalah keluarga pertanian yaitu mencapai rata-rata 73,55 persen tiap desa/kelurahan. Rata-rata persentase penduduk laki-laki sebesar 50,38 persen. Hal ini menunjukkan bahwa jumlah penduduk laki-laki lebih banyak dibandingkan jumlah penduduk perempuan. 
Tabel 2.

Nilai Statistik Deskriptif Peubah Penyerta Unit Desa/Kelurahan

\begin{tabular}{lcccc}
\hline \multicolumn{1}{c}{ Peubah Penyerta } & Min & Maks & $\begin{array}{c}\text { Rata- } \\
\text { Rata }\end{array}$ & $\begin{array}{c}\text { Simpangan } \\
\text { Baku }\end{array}$ \\
\hline $\begin{array}{l}\text { Persentase penduduk laki-laki } \\
\text { Persentase keluarga pertanian }\end{array}$ & 28,45 & 70,20 & 50,38 & 3,59 \\
$\begin{array}{l}\text { Jumlah Surat Keterangan Miskin } \\
\text { (SKM) yang dikeluarkan pemerintah }\end{array}$ & 0,00 & 100,00 & 73,55 & 26,22 \\
desa & 0,00 & 1341,00 & 63,13 & 101,02 \\
Jumlah SMA/SMK/MA dan & & & & \\
Perguruan Tinggi & 0,00 & 10,00 & 0,38 & 0,85 \\
Jumlah industri & 0,00 & 610,00 & 7,68 & 26,92 \\
Jumlah pasar & 0,00 & 1025,00 & 32,29 & 61,05 \\
Jumlah hotel/penginapan & 0,00 & 16,00 & 0,13 & 0,76 \\
\hline
\end{tabular}

Jumlah industri kecil menengah yang diharapkan bisa menyerap tenaga kerja juga jumlahnya sangat kecil. Rata-rata hanya sekitar 7,68 unit industri di setiap desa/kelurahan di Provinsi Jambi. Di sisi lain, Surat Keterangan Miskin (SKM) paling banyak yag dikeluarkan oleh pemerintah desa/kelurahan berjumlah 1.341 surat dengan rata-rata SKM yang dikeluarkan oleh desa/kelurahan sebesar 63 surat.

Berdasarkan Tabel 2 terlihat bahwa terdapat desa yang tidak memiliki SMA/SMK/MA dan Perguruan Tinggi sama sekali, serta terdapat desa/kelurahan yang memiliki 10 SMA/SMK/MA dan Perguruan Tinggi. Rata-rata jumlah industri di desa/kelurahan sebesar 7,68 unit, industri yang dimaksud di sini adalah Industri Mikro Kecil (IMK) dari kulit, kayu, logam mulia atau bahan logam, anyaman, gerabah/keramik/batu, kain/tenun, makanan minuman, dan lainnya. Rata-rata jumlah pasar dan pertokoan di desa/kelurahan sebesar 32., 9 unit. Jumlah pasar di sini meliputi pasar dengan bangunan permanen, pasar dengan bangunan semi permanen, dan pasar tanpa bangunan. Selain itu, banyak desa/kelurahan yang tidak terdapat hotel dan penginapan, hal ini bisa terlihat dari rata-rata keberadaan hotel dan penginapan yang kecil sebesar 0,13 tetapi terdapat juga desa/kelurahan yang memiliki 10 hotel dan penginapan. Perbedaan hotel dan penginapan terletak pada izin usahanya sebagai hotel atau penginapan.

Tabel 3.

Korelasi Pearson Peubah Penyerta terhadap Jumlah Pengangguran

\begin{tabular}{ccc}
\hline \multirow{2}{*}{ Peubah } & \multicolumn{2}{c}{$\mathrm{Y}$} \\
\cline { 2 - 3 } & Korelasi & Nilai $\mathrm{p}$ \\
\hline X1 & $-0,049$ & 0,631 \\
X2 & 0,002 & 0,982 \\
X3 & 0,116 & 0,640 \\
X4 & 0,048 & 0,253 \\
X5 & 0,117 & 0,250 \\
X6 & 0,159 & 0,116 \\
X7 & 0,207 & 0,040 \\
\hline
\end{tabular}

Berdasarkan Tabel 3 telihat bahwa hubungan linier antara peubah-peubah penyerta terhadap pengangguran sangat kecil. Peubah X1 satu-satunya yang bersifat negatif. Tanda negatif pada nilai 
korelasi menandakan bahwa ketika persentase jumlah penduduk laki-laki tiap desa/kelurahan meningkat maka secara umum akan mengurangi jumlah pengangguran di desa/kelurahan tersebut, begitu juga sebaliknya. Peubah X2 - X7 menunjukkan tanda positif. Hal ini memberikan gambaran bahwa jika persentase keluarga pertanian, jumlah Surat Keterangan Miskin (SKM) yang dikeluarkan pemerintah desa/kelurahan, jumlah SMA/sederajat dan PT, jumlah industri, jumlah pasar/pertokoan, serta jumlah hotel/pertokoan meningkat maka secara umum akan menambah jumlah pengangguran di desa/kelurahan tersebut, begitu juga sebaliknya.

Hanya terdapat satu peubah yang berpengaruh nyata secara statistik mempengaruhi besarnya jumlah pengangguran tiap desa/kelurahan di Provinsi Jambi yaitu peubah jumlah hotel dan pertokoan. Dalam SAE ZIB sangat rentan untuk terjadinya kegagalan algoritma, dalam arti bahwa penggunaan peubah yang tepat sangat menentukan bisa terbentuk atau gagalnya terhadap model SAE ZIB. Korelasi antar peubah penyerta dengan pengangguran digunakan untuk dasar kombinasi dalam menentukan peubah yang digunakan dalam model. Penggunaan peubah penyerta dalam model lebih mengutamakan kepada kekonvergenan model, meskipun korelasi menunjukkan nilai yang sangat kecil atau tidak berpengaruh nyata secara statistik.

Data jumlah pengangguran unit desa/kelurahan diasumsikan terjadi overdispersi karena banyaknya nilai nol pada pada tersebut. Penyebab terjadinya overdispersi pada data disebabkan oleh sifat alami data, seperti nilai nol yang berlebihan sehingga menyebabkan ragam yang dihasilkan lebih besar dari rataan. Pada peubah respon biner $Y_{i}$, biasanya dimodelkan dengan model Binomial, dimana ragamnya adalah $\operatorname{var}\left(Y_{i}\right)=n_{i} \pi_{i}\left(1-\pi_{i}\right)$. Akan tetapi jika keragaman lebih besar dari yang diasumsikan, $\operatorname{var}\left(Y_{i}\right)>n_{i} \pi_{i}\left(1-\pi_{i}\right)$,

maka telah terjadi overdispersi pada data Binomial. Dalam kajian aplikasi dengan menggunakan data jumlah pengangguran unit desa/kelurahan yang bersifat Zero Inflated Binomial, akan tetapi perlu dibuktikan kebenrana terjadi overdispersi pada data tersebut. Perbadingan ragam menunjukkan bahwa data jumlah pengangguran Sakernas Agustus 2016 unit desa/kelurahan di Provinsi Jambi memiliki ragam $(0,7145)$ lebih besar dibandingkan dengan ragam teoritisnya $(0,5859)$ sehingga dapat disimpulkan bahwa telah terjadi overdispersi pada data Binomial di level unit.

Penelitian ini mengaplikasikan metode SAE ZIB untuk data jumlah pengangguran. Data jumlah pengangguran dimodelkan dengan model ZIB dalam SAE untuk mengatasi banyaknya nilai nol pada peubah yang diamati di level unit desa/kelurahan. Tesis ini menggunakan nilai inisialisasi dari model ZIB tanpa SAE untuk mencegah kegagalan algoritma dalam metode SAE ZIB. Berdasarkan pengalaman, pemilihan nilai inisialisasi dan peubah yang tepat merupakan hal-hal penting yang dapat mengatasi kegagalan algoritma. Hasil di Tabel 4 menunjukkan bahwa X4 = jumlah SMA/SMK/MA dan Perguruan Tinggi serta ragam acak area berpengaruh nyata terhadap peubah yang menjadi perhatian pada $\alpha=5 \%$. 
Tabel 4.

Penduga Parameter Metode SAE ZIB

\begin{tabular}{ccccccccc}
\hline \multirow{2}{*}{ Logit } & Parameter & Penduga & $\begin{array}{c}\text { Galat } \\
\text { Baku }\end{array}$ & db & Nilai-t & Pr $>|t|$ & \multicolumn{2}{c}{ SK 95\% } \\
\hline \multirow{2}{*}{$\pi$} & $\mathrm{X} 3$ & $-1,20$ & 3,63 & 97 & $-0,33$ & 0,74 & $-8,41$ & 6,02 \\
& $\mathrm{X} 6$ & $-10,32$ & 6,37 & 97 & $-1,62$ & 0,12 & $-22,96$ & 2,33 \\
\hline \multirow{2}{*}{$\mathrm{p}$} & $\mathrm{X} 4$ & 3,29 & 1,21 & 97 & 2,72 & 0,01 & $-2,29$ & 8,87 \\
& $\mathrm{X} 7$ & 1,67 & 1,64 & 97 & 1,02 & 0,31 & $-1,57$ & 4,92 \\
\hline & ragam v & 10,65 & 4,79 & 97 & 2,23 & 0,03 & 1,15 & 20,15 \\
\hline
\end{tabular}

Peubah penyerta terpilih untuk model logit pertama adalah peubah X3 (jumlah Surat Keterangan Miskin yang dikeluarkan pemerintah desa) dan X6 (jumlah pasar dan pertokoan). Untuk model pertama adalah untuk bagian data tidak nol dari data contoh melalui fungsi penghubung logit,

$\operatorname{logit}\left(\hat{\pi}_{i j}\right)=\log \left(\frac{\widehat{\pi}_{i j}}{1-\widehat{\pi}_{i j}}\right)=\hat{\alpha}_{3} X 3+\hat{\alpha}_{6} X 6+v_{n z, i}$

dimana $\mathrm{i}=1,2, \ldots, 11$; dan $\mathrm{j}=1,2, \ldots, n_{\mathrm{i}}$, $n_{\mathrm{i}}$ adalah banyaknya desa/kelurahan di area i dan $v_{n z i_{i} \sim} N\left(0, \sigma_{v, n z}^{2}\right)$. Model kedua adalah model yang mendiskripsikan peluang untuk nilai tidak nol menggunakan peubah X4 (jumlah SMA/SMK/MA dan Perguruan Tinggi) dan $\mathrm{X} 7$ (jumlah hotel dan $\left(1-p_{i j}\right)=P\left(\delta_{i j}=1\right)=P\left(y_{i j} \neq 0\right)$, yaitu

$\operatorname{logit}\left(\hat{p}_{i j}\right)=\log \left(\frac{\hat{p}_{i j}}{1-\hat{p}_{i j}}\right)=\hat{\beta}_{4} X 4+\hat{\beta}_{7} X 7+v_{z_{i} i}$

dimana $\mathrm{i}=1,2, \ldots, 11 ; \mathrm{j}=1,2, \ldots, n_{\mathrm{i}} ; n_{\mathrm{i}}$ adalah banyaknya desa/kelurahan di area $\mathrm{i}$ dan $v_{z, i} \sim N\left(0, \sigma_{v, z}^{2}\right)$.

Tabel 5 menyajikan hasil penelitian ini berupa dugaan Tingkat Pengangguran Terbuka (TPT) dari metode SAE ZIB. Dugaan TPT dengan metode SAE ZIB di
Provinsi Jambi pada Agustus 2016 sebesar 3,88 persen, yang berarti bahwa terdapat sekitar 4 orang pengangguran dari 100 orang angkatan kerja. Hasil ini mirip dengan angka Tingkat Pengangguran Terbuka (TPT) Agustus 2016 Provinsi Jambi yang dipublikasikan oleh BPS, yaitu sebesar 4,00 persen. Pada Agustus 2016 hanya ada publikasi Tingkat Pengangguran Terbuka (TPT) pada level provinsi dan tidak ada publikasi pada level kabupaten/kota karena ketidakcukupan contoh untuk menduga Tingkat Pengangguran Terbuka (TPT) hingga level kabupaten/kota sebagaimana tahun-tahun sebelumnya.

Tabel 5.

Hasil Dugaan TPT dan Galat Baku Metode SAE ZIB

\begin{tabular}{|c|c|c|c|}
\hline \multirow{2}{*}{\multicolumn{2}{|c|}{ Kabupaten/Kota }} & \multicolumn{2}{|c|}{ TPT (\%) } \\
\hline & & \multirow{2}{*}{$\begin{array}{c}\text { Dugaan } \\
3,48\end{array}$} & \multirow{2}{*}{$\begin{array}{c}\begin{array}{c}\text { Galat } \\
\text { Baku }\end{array} \\
0,0174\end{array}$} \\
\hline 1501 & Kerinci & & \\
\hline 1502 & Merangin & 3,86 & 0,0152 \\
\hline 1503 & Sarolangun & 5,76 & 0,0164 \\
\hline 1504 & $\begin{array}{l}\text { Batang } \\
\text { Hari }\end{array}$ & 2,62 & 0,0184 \\
\hline 1505 & $\begin{array}{l}\text { Muaro } \\
\text { Jambi }\end{array}$ & 1,17 & 0,0153 \\
\hline 1506 & $\begin{array}{l}\text { Tanjung } \\
\text { Jabung } \\
\text { Timur }\end{array}$ & 4,79 & 0,0159 \\
\hline 1507 & Tanjung & 3,77 & 0,0131 \\
\hline
\end{tabular}




\begin{tabular}{|c|c|c|c|}
\hline \multirow{2}{*}{\multicolumn{2}{|c|}{ Kabupaten/Kota }} & \multicolumn{2}{|c|}{ ТPТ (\%) } \\
\hline & & Dugaan & $\begin{array}{l}\text { Galat } \\
\text { Baku }\end{array}$ \\
\hline & Jabung & & \\
\hline & Barat & & \\
\hline 1508 & Tebo & 2,24 & 0,0182 \\
\hline 1509 & Bungo & 5,67 & 0,0136 \\
\hline \multirow[t]{2}{*}{1571} & Kota & 4,74 & 0,0153 \\
\hline & Kota & & \\
\hline \multirow[t]{3}{*}{1572} & Sungai & 4,35 & 0,0174 \\
\hline & Penuh & & \\
\hline & $\begin{array}{l}\text { Provinsi } \\
\text { Jambi }\end{array}$ & 3,88 & 0,0160 \\
\hline
\end{tabular}

Metode SAE ZIB dan publikasi BPS menghasilkan dugaan yang sama terhadap hasil Tingkat Pengangguran Terbuka (TPT) di Provinsi Jambi, yaitu terdapat 4 orang menganggur dari 100 orang angkatan kerja. Dapat disimpulkan bahwa, metode SAE ZIB cukup akurat untuk menduga Tingkat Pengangguran Terbuka (TPT) pada level kabupaten/kota yang sebelumnya tidak dipublikasikan oleh BPS.

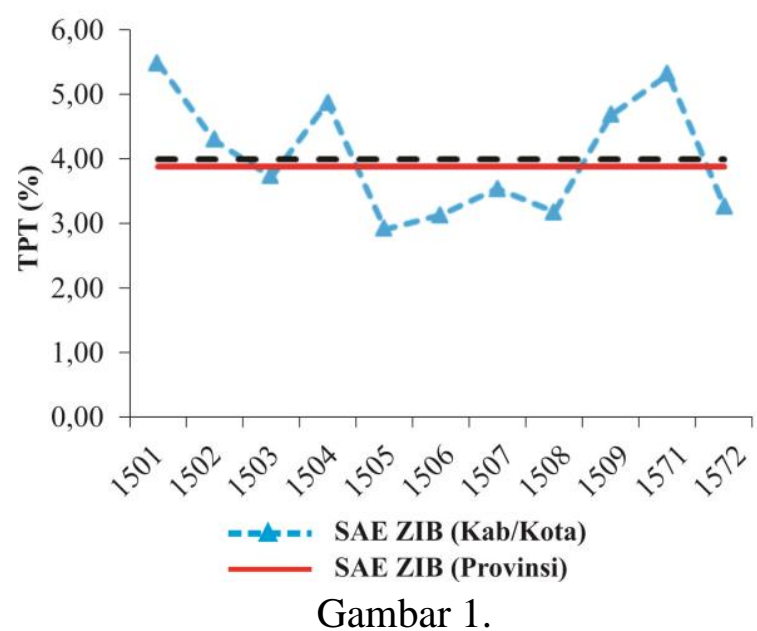

Grafik Garis Hasil Dugaan TPT Metode SAE ZIB dan Publikasi BPS

Tabel 6 menunjukkan nilai Fit Statistics dari metode SAE ZIB. Nilai Fit Statistics dari metode pendugaan area kecil dengan model Zero Inflated Binomial pada data pengangguran adalah relatif kecil. Hal
Ini menunjukkan bahwa model yang digunakan sudah baik.

Tabel 6.

Fit Statistics dari Metode SAE ZIB

\begin{tabular}{lc}
\hline \multicolumn{2}{c}{ Fit Statistics } \\
\hline -2 Log Likelihood & 102,2 \\
AIC & 119,2 \\
AICC & 119,9 \\
BIC & 131,2 \\
\hline
\end{tabular}

Menurut Rao dan Molina (2013), suatu domain atau area dianggap besar jika ukuran contoh dari area spesifik cukup dianggap besar jika ukuran contoh dari area spesifik cukup besar untuk melakukan pendugaan langsung dengan ketelitian yang memadai. Suatu area dianggap kecil jika ukuran contoh dari area tertentu tidak cukup besar sehingga pendugaan langsung akan menghasilkan statistik dengan ketelitian yang memadai.

Data Sakernas Agustus 2016 belum cukup untuk melakukan pendugaan langsung pada level kabupaten/kota dikarenakan untuk menduga angka pengangguran pada level kabupaten/kota membutuhkan contoh 20.000 Blok Sensus atau 200.000 rumah tangga. Pada Sakernas Agustus 2016 BPS hanya melakukan survei di 5.000 Blok Sensus yang hanya cukup untuk menduga angka pengangguran pada level provinsi. Blok Sensus Sakernas Agustus 2016 sama dengan Blok Sensus Sakernas Februari tahun 2015

\section{SIMPULAN}

Hasil dugaan Tingkat Pengangguran Terbuka (TPT) Provinsi Jambi dengan metode SAE ZIB sama dengan yang dipublikasikan oleh BPS, yaitu 4 (empat) 
orang menganggur dari 100 orang angkatan kerja. Kelebihan metode pendugaan area kecil dengan model ZIB adalah mampu menghasilkan dugaan Tingkat Pengangguran Terbuka (TPT) tingkat kabupaten/kota dengan akurasi yang baik, yang BPS tidak bisa mengeluarkan dugaan tersebut. Metode pendugaan area kecil dengan model ZIB layak jika digunakan untuk menghasilkan dugaan Tingkat Pengangguran Terbuka (TPT) Agustus $2016 \quad$ tingkat kabupaten/kota di Provinsi Jambi yang sebelumnya tidak dihasilkan oleh BPS karena ketidakcukupan contoh.

Metode SAE ZIB yang dikembangkan dalam penelitian ini bisa menjadi salah satu metode untuk pendugaan Tingkat Pengangguran Terbuka (TPT) tingkat kabupaten/kota dengan menggunakan data Sakernas Februari yang sebelumnya hanya untuk menduga Tingkat Pengangguran Terbuka (TPT) hingga tingkat provinsi, sehingga informasi tentang ketenagakerjaan dan perubahannya dapat dipantau dalam waktu yang relatif singkat (semesteran) seiring dengan perkembangan otonomi daerah.

Metode pendugaan area kecil dengan model ZIB dapat digunakan untuk menghasilkan dugaan Tingkat Pengangguran Terbuka (TPT) unit desa/kelurahan baik yang tersurvei maupun tidak tersurvei. Angka ini bisa menjadi gambaran keingintahuan pengguna data akan kondisi pengangguran di seluruh desa/kelurahan yang sebelumnya tidak pernah dihasilkan oleh BPS sehingga diharapkan akan lebih mampu menjawab tuntutan kebutuhan data ketenagakerjaan.

\section{DAFTAR PUSTAKA}

[BPS] Badan Pusat Statistik. (2016). Pedoman Pencacahan Sakernas Semesteran 2016. Jakarta: BPS.

[BPS] Badan Pusat Statistik Provinsi Jambi. (2017). Indikator Kesejahteraan Rakyat Provinsi Jambi 2016. Jambi: BPS Provinsi Jambi.

Bodro, P.I., Usman, H., Maniar, S.B., Wicaksono, F. (2016). Official Statistics Sosial Kependudukan. Bogor: Penerbit In Media.

Chandra, H., Sud, C. (2012). Small Area Estimation for Zero-Inflated Data. Communications in Statistics - Simulation and Computation. 41(5). 632-643.

Fay, R.E., Herriot, R.A. (1979). Estimates of Income for Small Places: An Application of James Stein Procedures to Census Data. Journal of the American Statistical Association. 74. 269-277.

Hall, D.B. (2000). Zero Inflated Poisson and Binomial Regression with random effects: a case study. Biometrics. 56: 1030 - 1039.

Hardin, J.W., Hilbe, J.M. (2007). Generalized Linier Models and Extensions. Texas: Stata Press.

Hinde, J., and Demetrio, C.G.B. (2007). Overdispersion: Models and Estimation A short Course for SINAPE 1998. Sao Paulo: Associacio Brasileira de Estatisca. 
Krieg, S., Boonstra. H.J., Smeets, M. (2015). Small Area Estimation with Zero-Inflated Data - A Simulation Study. Statistics Netherlands, Discussion Paper. 1: 1-45.

Kurnia, A., Notodiputro, K.A. (2008). Pendekatan Generalized Additive Mixed Models dalam Pendugaan Parameter pada Small Area Estimation. Journal Sains MIPA, Desember 2007, Vol. 13, No. 3, hal. 145 - 151.

Rao, J.N.K. (2003). Small Area Estimation. New York: John Wiley and Sons.

Rao, J.N.K., Molina, I. (2015). Small Area Estimation Second Edition. New York: John Wiley and Sons, Inc. 